\title{
耐震壁を有する立体剛節骨組の不同沈下と横力負担 係数の性状について
}

正会員村橋 久 昭*

§1.はしがき，耐震壁は水平力を負担する重要な権 造体であるが，陾震壁の不同沈下による性状はいまだよ く把握されていない。これよりさきに龂留した不闰沈下

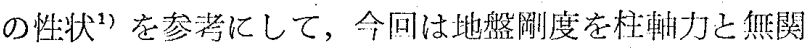
係に仮定した場合に，不同沈下が如何なる性状を示すか を検傠し，さらに横力負担係数の変化を調べた。

なお，不同沈下の算定は既報2)に從い，而震壁の壁板 は愿さにより來屈 ${ }^{3)}$ を考慮して低減率 $\omega^{4}$ を用いた。

\$2. 骨組の概要亡地盤の剛度 例題の而震壁を有す る立体剛節骨組の配置は図一1 に示し，その断面および

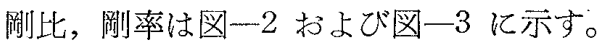

また，地盤剧度は次の 2 通りを仮定し，その值 ( 図一1 に示す。

[A] およそ柱軸力に応じて定めた場合……....

[B] 柱軸力と無関係に定めた場合……............

§3. 不同沈下の結果酎震壁を有する骨組の不同沈 下を上記の仮定にもとずいて算定すると, 基整反力 $F$ は図-1 に，基礎の沈下は図一4に示す結果を得た。

なお，西均沈下は［A] の場合 $1.93 \mathrm{~cm} ，$ ，B］の場 合 $3.941 \mathrm{~cm}$ であった。

\$4. 横力負担係数について 今，4通りラーメンに ついて, 各層に $P=40 \mathrm{t}$ の水平加を加光た場合5) の曲 げ変形およびせん断変形による横力㷛担媇数 ${ }^{6\rangle}$ 之基礎の 沈下による横力負担係数を比較すれば表一1 のようにな る。乙の場合の基礎の沈下は地盤剛度 $\lambda_{B}$ の状態で，し かも相対沈下は耐震壁の重心線の平均沈下により算定し た。その結果，相対沈下量は $0.033 \mathrm{~cm}$ で，回軽牦 $\theta$ は $0.043 \times 10^{-3}$ であった。

§5.むすび 阡算の結果から次のようなととが判

明した。

（1）地盤剛度をおよと柱軸力に応じて定めた場合全 体的に相対沈下暈は少ない。例えば $\mathrm{A}$ 道り耐震臂の回 垤角は $0.029 \times 10^{-3}$ 程度であった。

（2）相対沈下は横材の剛率が大さければ地盤㴊度が 柱軸力に無関係に変化していても，ひどく大きくはなら なかった。また 1 通り耐震壁の回転角は $0.034 \times 10^{-3}$ で あった。

（3） 4 通りラーメン（中廊下形式耐震壁）において 相対沈下 (回転角 $0.043 \times 10^{-3}$ ) 飞上る棈力負担係数の 低下は 2 層以上で $7 \%$ 搔，最下層で $10 \%$ 䂈であった。

謝 辞：本研究にあたって御指導をいただいた熊大石田教授に 感謝致します。

[参考文献]

1)，4）右田，村橋，中津: 两付震に関する研究（不同沈下の 性状について, その 1), 日本建築学会九州支部研究報告 第 14 号 昭和 40 年 2 月

2）右田 健览：立体剛節骨組の不同沈下量算定法について, 日本建築学会論文報告集第 103 号, 昭和 39 年 10 月

3）富井 政英：鉄筋コンクリート板のせん断抵抗に関卞る研 究, 生産技術研究所蛛告 第 6 巻第 3 号, 昭和 32 年 1 月

5) 右田, 村橋: 中廊下形式耐震壁の一解法, 日本建築学会 論文報告集 第 103 号, 昭和 39 年 10 月

6) 武藤 清: 建築学大系 14 , 而震棓算法

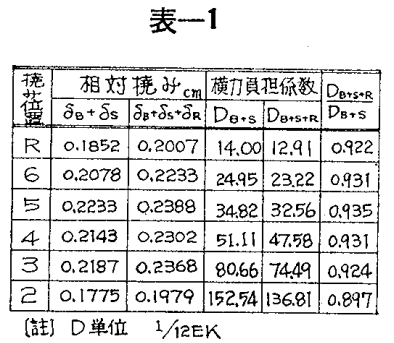

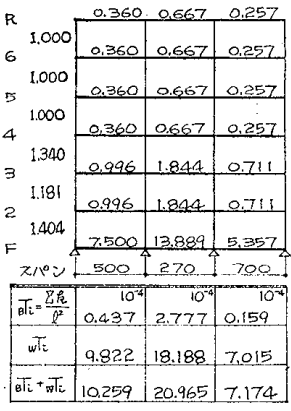

図一3

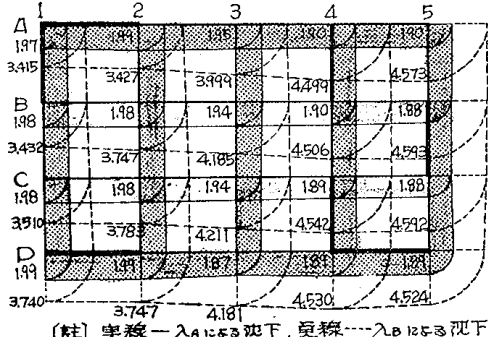

図-4

* 熊本大学助教授 